\title{
Uji Aktivitas Antioksidan Minyak Sereh Wangi (Cymbopogon nardus (L.) Rendle), Minyak Nilam (Pogostemon cablin Benth.) dan Minyak Pala (Myristica fragrans Houtt.) \\ (Antioxidant Activity Test of Citronella Oil (Cymbopogon nardus (L.) Rendle), Patchouli Oil (Pogostemon cablin Benth.) and Nutmeg Oil (Myristica fragrans Houtt.))
}

\author{
Amalia Rachmatillah ${ }^{1}$, Dian Hasni ${ }^{1}$, Yuliani Aisyah ${ }^{1 *}$ \\ ${ }^{1}$ Program Studi Teknologi Hasil Pertanian, Fakultas Pertanian, Universitas Syiah Kuala \\ *Corresponding author: yuliani.aisyah@ unsyiah.ac.id
}

\begin{abstract}
Abstrak. Minyak sereh wangi, minyak nilam dan minyak pala merupakan minyak atsiri yang berpotensi sebagai antioksidan dan merupakan minyak atsiri unggulan dari Aceh. Penelitian ini bertujuan untuk mengukur aktivitas antioksidan dan daya hambat dari ketiga minyak atsiri dan campurannya. Hasil penelitian menunjukkan bahwa semua perlakuan jenis minyak memiliki potensi sebagai antioksidan karena memiliki aktivitas antioksidan dengan intensitas yang sangat kuat. Berdasarkan uji aktivitas antioksidan yang telah dilakukan diperoleh nilai $\mathrm{IC}_{50}$ terkuat yaitu pada minyak pala $\left(M_{3}\right)$ sebesar 3,34 ppm dengan persentase inhibisi yaitu $47,35 \%$.
\end{abstract}

Kata kunci : Antioksidan, minyak atsiri.

Abstract. Citronella oil, patchouli oil, and nutmeg oil are essential oils that have the potential as antioxidants and are superior essential oils from Aceh. This study aims to measure the antioxidant activity and inhibition of the three essential oils and their mixtures. The results showed that all types of oil treatment have potential as antioxidants because they have antioxidant activity with very strong intensity. Based on the antioxidant activity test was done $\mathrm{IC}{ }_{50}$ in the strongest nutmeg oil $\left(\mathrm{M}_{3}\right)$ of $3.34 \mathrm{ppm}$ with an inhibition percentage is $47.35 \%$.

Keywords: Antioxidant, essential oil.

\section{PENDAHULUAN}

Minyak sereh wangi, minyak nilam dan minyak pala merupakan minyak atsiri yang berpotensi sebagai antioksidan dan merupakan minyak atsiri unggulan dari Provinsi Aceh. Kandungan antioksidan dalam minyak sereh wangi, minyak nilam dan minyak pala dapat digunakan untuk mencegah kerusakan kulit yang disebabkan oleh salah satunya yaitu radikal bebas.

Berdasarkan beberapa hasil penelitian yang telah dilakukan sebelumnya diketahui bahwa aktivitas antioksidan pada jenis tumbuhan seperti sereh wangi, nilam dan pala dikaitkan dengan adanya flavonoid, polifenol, alkaloid, lignin, terpenoid, karotenoid dan lain-lain (Promila dan Madan, 2018). Kemudian dari penjelasan yang telah dipaparkan diatas, penelitian ini dilakukan untuk meneliti potensi aktivitas antioksidan yang dimiliki ketiga minyak atsiri diatas sebagai bahan baku dalam pembuatan krim kulit.

\section{METODE PENELITIAN}

Penelitian ini dilakukan di Laboratorium Analisis Hasil Pangan dan Hasil Pertanian Jurusan Teknologi Hasil Pertanian dan Laboratorium Biokimia Fakultas Matematika dan Ilmu Pengetahuan Alam (MIPA) Jurusan Kimia, Darussalam Banda Aceh. 


\section{MATERI DAN METODE}

\section{Minyak Atsiri}

Minyak sereh wangi yang diperoleh dari ARC (Atsiri Research Center) USK, minyak nilam diperoleh dari RAMU (CV Koetaradja Aromatic) dan minyak pala diperoleh dari ARC (Atsiri Research Center) USK.

\section{Metode Penelitian}

Penelitian ini menggunakan Rancangan Acak Kelompok (RAK) non-faktorial yang terdiri dari faktor jenis minyak atsiri (M) yang terdiri atas 7 (tujuh) taraf yaitu : minyak sereh wangi $\left(\mathrm{M}_{1}\right)$, minyak nilam $\left(\mathrm{M}_{2}\right)$, minyak pala $\left(\mathrm{M}_{3}\right)$, minyak sereh wangi + minyak nilam $\left(\mathrm{M}_{4}\right)$, minyak sereh wangi + minyak pala $\left(\mathrm{M}_{5}\right)$, minyak nilam + minyak pala $\left(\mathrm{M}_{6}\right)$, dan minyak sereh wangi + minyak nilam + minyak pala $\left(\mathbf{M}_{7}\right)$. Pembanding yang digunakan dalam penelitian ini yaitu asam galat.

\section{Prosedur Pengujian di Laboratorium}

Penetapan nilai $\mathrm{IC}_{50}$ dilakukan terhadap senyawa DPPH (1,1-difenil-2-pikrilhidrazil) dengan prosedur yaitu sebagai berikut:

1. Pembuatan larutan uji

Dibuat larutan induk $1000 \mathrm{ppm}$ larutan minyak atsiri dengan melarutkan 0,010 g minyak atsiri dengan pelarut metanol dalam labu ukur $10 \mathrm{ml}$. Kemudian dari larutan induk $1000 \mathrm{ppm}$ dibuat variasi konsentrasi 20,40,60,80, dan 100 ppm dengan memipet $1 \mathrm{ml}$ dan dimasukkan ke dalam labu ukur $10 \mathrm{ml}$ dan diencerkan dengan pelarut metanol sampai garis batas.

2. Pembuatan larutan DPPH

Ditimbang DPPH 0,0039 mg dan dilarutkan dengan metanol hingga $100 \mathrm{ml}$ kemudian ditutup dengan aluminium foil.

3. Pembuatan larutan blanko

Dipipet $2 \mathrm{ml}$ larutan DPPH $(0,1 \mathrm{mM})$ ke dalam tabung reaksi lalu ditambahkan metanol sebanyak $2 \mathrm{ml}$ dan dihomogenkan kemudian diinkubasi dalam ruangan gelap selama 30 menit. Kemudian diukur absorbansinya dengan panjang gelombang $517 \mathrm{~nm}$.

4. Pembuatan larutan asam galat

Ditimbang sebanyak $1 \mathrm{mg}$ kemudian dilarutkan dengan metanol dalam labu ukur $10 \mathrm{ml}$. Larutan di homogenkan kemudian dilakukan pengenceran 20,40,60,80 dan 100 ppm.

5. Uji aktivitas antioksidan

Masing-masing larutan uji dipipet $2 \mathrm{ml}$ dimasukkan ke dalam tabung reaksi dan ditambahkan $2 \mathrm{ml}$ larutan DPPH 0,1 mM lalu dihomogenkan dan diinkubasi pada suhu kamar selama 30 menit dan diukur absorbansinya dengan panjang gelombang $517 \mathrm{~nm}$.

6. Pengukuran $\mathrm{IC}_{50}$

Nilai $\mathrm{IC}_{50}$ dihitung dari kurva regresi linier antara \% inhibisi serapan dengan berbagai konsentrasi larutan uji.

\section{HASIL DAN PEMBAHASAN}

Berdasarkan hasil penelitian diperoleh nilai persentase inhibisi pada minyak atsiri berkisar antara 15,52\% hingga 60,62\% dengan rata-rata persen inhibisi minyak atsiri adalah $34,06 \%$. Pada Gambar 1, dapat dilihat bahwa adanya perbedaan aktivitas antioksidan dari jenis minyak. Perbedaan tersebut diduga disebabkan oleh jenis minyak dan jumlah senyawa antioksidan yang terdapat pada minyak tersebut. 


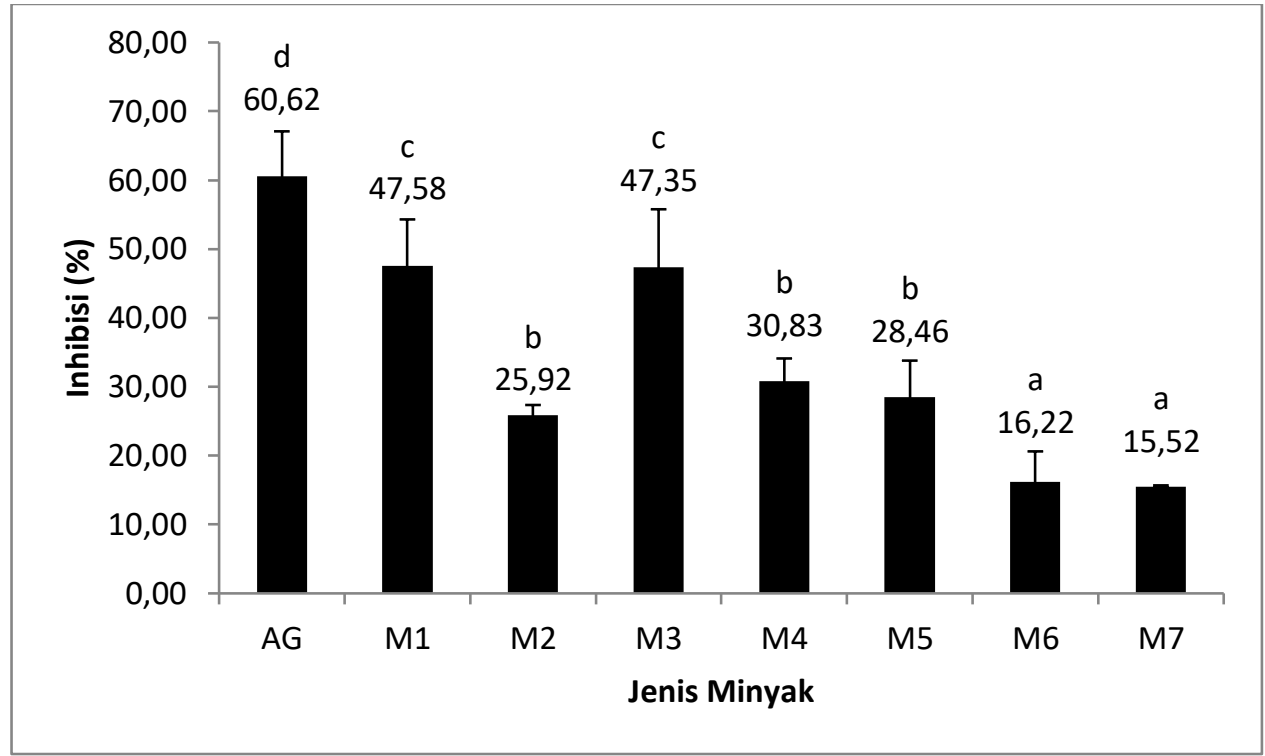

Gambar 1. Pengaruh Jenis Minyak pada Aktivitas Antioksidan

Keterangan : $\mathbf{M}_{1}=$ Minyak Sereh Wangi, $\mathbf{M}_{2}=$ Minyak Nilam,

$\mathrm{M}_{3}=$ Minyak Pala, $\mathrm{M}_{4}=$ Minyak Sereh Wangi + Minyak Nilam,

$\mathrm{M}_{5}=$ Minyak Sereh Wangi + Minyak Pala, $\mathbf{M}_{6}=$ Minyak Nilam +

Minyak Pala dan $\mathrm{M}_{7}=$ Minyak Sereh Wangi +

Minyak Nilam + Minyak Pala

Pada Gambar 1, berdasarkan jenis minyak aktivitas antioksidan paling tinggi yaitu terdapat pada minyak sereh wangi $\left(\mathrm{M}_{1}\right)(47,58 \%)$ dan minyak pala $\left(\mathrm{M}_{3}\right)(47,35 \%)$, kedua taraf tersebut tidak berbeda nyata. Sedangkan aktivitas antioksidan paling rendah yaitu terdapat pada perlakuan $\mathrm{M}_{7}(15,52 \%)$, yang tidak berbeda nyata dengan $\mathrm{M}_{6}(16,22 \%)$.

Pada Gambar 1 juga dapat dilihat bahwa pada minyak yang dicampur seperti $\mathrm{M}_{4}$ yang merupakan campuran dari minyak sereh wangi $\left(\mathbf{M}_{1}\right)$ dan minyak nilam $\left(\mathbf{M}_{2}\right)$ memiliki persentase inhibisi yang rendah jika dibandingkan dengan minyak sereh wangi $\left(\mathbf{M}_{1}\right)$ hal ini terjadi diperkirakan karena persentase inhibisi dari minyak nilam $\left(\mathrm{M}_{2}\right)$ lebih rendah sehingga ketika kedua minyak tersebut dicampur diperoleh nilai inhibisi yang berada diantara keduanya. Namun, campuran minyak dengan formulasi minyak pala, nilai persentase inhibisinya mengalami penurunan. Minyak sereh wangi dan minyak pala memiliki persen inhibisi yang cukup tinggi, akan tetapi apabila kedua minyak tersebut dicampurkan, persen inhibisi dari keduanya lebih rendah. Hal ini kemungkinan disebabkan, kedua minyak tersebut dan campuran minyak lainnya tidak menunjukkan sinergis aktivitas ketika digabungkan (Hossain et al., 2016).

\section{Nilai IC50 Minyak Atsiri}

Tabel 1. Intensitas antioksidan

\begin{tabular}{lc}
\hline Nilai $\mathrm{IC}_{50}(\mathrm{ppm})$ & Intensitas Antioksidan \\
\hline$<50$ & Sangat kuat \\
$50-100$ & Kuat \\
$100-250$ & Sedang \\
$250-500$ & Lemah \\
$>500$ & Tidak Aktif \\
\hline
\end{tabular}

Sumber : Molyneux (2004).

Menurut Molyneux (2004) nilai $\mathrm{IC}_{50}$ adalah konsentrasi yang menghambat aktivitas radikal bebas sebesar 50\%. Nilai IC 50 yang didapatkan dapat digunakan untuk mengkategorikan 
aktivitas antioksidan. Untuk mengkategorikan intensitas dari aktivitas antioksidan dapat dilihat pada Tabel 1. Berdasarkan analisa regresi ke tujuh jenis minyak atsiri pada rentang konsentrasi 20-100 ppm, nilai IC $_{50}$ minyak atsiri pada penelitian ini berkisar antara 0,65 hingga 34,12 atau dapat dilihat pada Tabel 2.

Tabel 2. Nilai $\mathrm{IC}_{50}$ Minyak Atsiri

\begin{tabular}{lcc}
\hline \multicolumn{1}{c}{ Jenis Minyak $(\mathrm{M})$} & $\mathrm{IC}_{50}(\mathrm{ppm})$ & Intensitas Antioksidan \\
\hline Minyak Sereh Wangi $\left(\mathrm{M}_{1}\right)$ & 3,80 & Sangat Kuat \\
Minyak Nilam $\left(\mathrm{M}_{2}\right)$ & 34,12 & Sangat Kuat \\
Minyak Pala $\left(\mathrm{M}_{3}\right)$ & 3,34 & Sangat Kuat \\
Minyak Sereh Wangi + Minyak & 6,46 & Sangat Kuat \\
Nilam $\left(\mathrm{M}_{4}\right)$ & & \\
Minyak Sereh Wangi + Minyak & 6,81 & Sangat Kuat \\
Pala $\left(\mathrm{M}_{5}\right)$ & 10,99 & Sangat Kuat \\
Minyak Nilam + Minyak Pala $\left(\mathrm{M}_{6}\right)$ & 16,36 & Sangat Kuat \\
Minyak Sereh Wangi + Minyak & 0,65 & Sangat Kuat \\
Nilam + Minyak Pala $\left(\mathrm{M}_{7}\right)$ & & \\
Asam Galat (AG) &
\end{tabular}

Berdasarkan Tabel 2 dapat dilihat bahwa semua minyak yang digunakan pada penelitian ini memiliki intensitas antioksidan yang sangat kuat. Berdasarkan penelitian yang telah dilakukan oleh Rastuti et al. (2020) menyatakan bahwa kandungan pada minyak sereh wangi $\left(\mathrm{M}_{1}\right)$ yaitu geraniol dan elemol merupakan merupakan kelompok alkohol yang telah dilaporkan potensinya sebagai antioksidan. Menurut Hariyanti et al. (2019) menyatakan bahwa patchouli alkohol yang terdapat pada minyak nilam $\left(\mathrm{M}_{2}\right)$ merupakan senyawa alkohol seskuiterpen yang berpotensi sebagai antioksidan, minyak nilam juga mempunyai komponen fenol dan terpen yang juga memiliki efek sebagai antioksidan. Berdasarkan penelitian yang telah dilakukan oleh Kapoor et al. (2013) menyatakan bahwa gugus fenol memiliki peran penting dalam aktivitas antioksidan sehingga senyawa fenolik seperti terpeniol-4, metil eugenol, trans-isoeugenol dan trans-metil eugenol dalam minyak pala $\left(\mathrm{M}_{3}\right)$ memiliki aktivitas antioksidan. Minyak pala memiliki aktivitas antioksidan yang kuat karena jumlah komponen fenolik yang terdapat pada minyak tersebut lebih banyak.

\section{KESIMPULAN DAN SARAN}

Semua perlakuan jenis minyak memiliki potensi sebagai antioksidan karena memiliki aktivitas antioksidan dengan intensitas yang sangat kuat. Berdasarkan uji aktivitas antioksidan yang telah dilakukan diperoleh nilai $\mathrm{IC}_{50}$ terkuat yaitu pada minyak sereh wangi $\left(\mathrm{M}_{1}\right)$ dan minyak pala $\left(\mathrm{M}_{3}\right)$ sebesar 3,80 ppm dan 3,34 ppm dengan masing-masing persentase inhibisi yaitu $47,58 \%$ dan $47,35 \%$.

\section{DAFTAR PUSTAKA}


Hariyanti E, Hanani, Dayatri DY. 2019. Phytochemical Identification and Antioxidant Activity of Essential Oil of Pogostemon cablin Benth. Cultivated in Java Island Indonesia. International Journal of Phytopharmacy. 9(6) : 1-7.

Hossain F, Follet P, Vu KD, Harich M, Salmieri S, Lacroix, M. 2016. Evidence for Synergistic Activity of Plant-Derived Essential Oil Againts Fungal Pathogens of Food. Food Microbiology. $53: 24-30$.

Integrated Taxonomic Information System. 2020. Taxonomic Hierarchy : Cymbopogon nardus (L.)

Rendle. https://www.itis.gov/servlet/SingleRpt/SingleRpt?search topic=TSN\&search value=41615\#n ull. Diakses tanggal : 01 Juni 2020.

Integrated Taxonomic Information System. 2020. Taxonomic Hierarchy : Myristica fragrans Houtt.

https://www.itis.gov/servlet/SingleRpt/SingleRpt?search topic=TSN\&search value=18125\#n ull. Diakses tanggal : 05 September 2020.

Integrated Taxonomic Information System. 2020. Taxonomic Hierarchy : Pogostemon cablin (Blanco)

https://www.itis.gov/servlet/SingleRpt/SingleRpt?search topic=TSN\&search value=506020\# null. Diakses tanggal : 05 September 2020.

Kapoor IPS, Singh B, Singh G, De Heluani CS, De Lampasona MP, Catalan CAN. 2013. Chemical Composition and Antioxidant Activity of Essential Oil and Oleoresins of Nutmeg (Myristica fragrans Houtt.) Fruits. International Journal of Food Properties. $16(5): 1059-1070$.

Molyneux P. 2004. The Use of The Stable Free Radical Diphenyl-picrylhydrazyl (DPPH) for Estimating Antioxidant Activity. J. Sci. Techonolgy. 26(2) : 211-219.

Promila, Madan VK. 2018. A Review on the Phytochemistry and Pharmacology of Cymbopogon citratus Stapf. (Lemongrass). The Pharma Innovation Journal. 7(3) : 300304.

Rastuti U, Diastuti H, Chasani M, Purwati, Hidayatullah R. 2020. Chemical Composition and Antioxidant Activities of Citronella Essential Oil Cymbopogon nardus (L.) Rendle Fraction. AIP Conference Proceedings. 2237(2) : 1-11. 